Brazilian Journal
of Chemical
Engineering

ISSN 0104-6632

Printed in Brazil

www.abeq.org.br/bjche

Vol. 26, No. 01, pp. 1 - 9, January - March, 2009

\title{
EFFECT OF CULTIVATION CONDITIONS ON GLUCOSE-6-PHOSPHATE DEHYDROGENASE PRODUCTION BY GENETICALLY MODIFIED Saccharomyces cerevisiae
}

\author{
F. G. Rossi ${ }^{1}$, D. P. Silva ${ }^{1,2, *}$ J. B. Almeida e Silva ${ }^{3}$, M. E. Taqueda ${ }^{4}$, \\ M. Vitolo ${ }^{1}$ and A. Pessoa-Jr ${ }^{1}$ \\ ${ }^{1}$ Department of Biochemical-Pharmaceutical Technology, School of Pharmaceutical Sciences, \\ University of São Paulo, 05508-000, São Paulo - SP, Brazil. \\ ${ }^{2}$ Institute for Biotechnology and Bioengineering, Centre of Biological Engineering, \\ Fax:: +(351) 253 678986, University of Minho, 4710-057, Gualtar - Braga, Portugal. \\ E-mail: silvadp@deb.uminho.pt, silvadp@hotmail.com \\ ${ }^{3}$ Department of Biotechnology, Engineering School of Lorena, \\ University of São Paulo, 12602-810, Lorena - SP, Brazil. \\ ${ }^{4}$ Chemical Engineering Dept, University of São Paulo, PQI, 05508-000, São Paulo, SP, Brazil.
}

(Submitted: September 5, 2006 ; Revised: June 17, 2008 ; Accepted: July 12, 2008)

\begin{abstract}
The objective of this research was to improve Glucose-6-phosphate dehydrogenase (G6PD) production by Saccharomyces cerevisiae W303-181, which carry the plasmid YEpPGK-G6PD, by varying the following cultivation conditions: $\mathrm{pH}$ value $(4.8,5.7$ and 6.6); inoculum concentration $(0.1,0.6$ and $1.1 \mathrm{~g} / \mathrm{L})$ and initial glucose concentration $(20.0,30.0$ and $40.0 \mathrm{~g} / \mathrm{L})$. The effect of those variables on G6PD production capability was studied by the application of response surface statistical analysis. The results showed that the highest G6PD production (1594.2 U/L), specific activity (1189.7 U/g $/$ cell $)$ and productivity (45.6 U/L.h) occurred at $\mathrm{pH} 4.8$, inoculum concentration of $0.1 \mathrm{~g} / \mathrm{L}$ and initial glucose concentration of $20.0 \mathrm{~g} / \mathrm{L}$, under agitation of $150 \mathrm{rpm}$ at $30^{\circ} \mathrm{C}$ after $36 \mathrm{~h}$. In this work, the strain expressed about 21 fold more activity than the wild $S$. cerevisiae strain, being an attractive and promising new source of this enzyme.

Keywords: Saccharomyces cerevisiae; Fermentation; Enzyme production; Glucose-6-phosphate
\end{abstract} dehydrogenase; Strain genetically modified.

\section{INTRODUCTION}

Glucose-6-phosphate dehydrogenase (G6PD) (EC1.1.1.49) is the first enzyme of the pentose phosphate pathway, which is found in almost all animal tissues and microorganisms. This enzyme is used as an analytical reagent for the measurement of hexokinase and creatin-kinase activities, ATP, as well as in enzyme immunoassays, either ELISA (enzyme-linked immunosorbent assay) or EMIT (enzyme multiplied immunotechnique), for diagnostic purposes (Bergmeyer, 1984; Ivison et al., 2000). The use of G6PD for measuring glucose in the presence of fructose constitutes an important tool for the detection of illegal sugar addition in the final products of the wine and fruit juice industries (Abrahão-Neto et al., 1997). This enzyme can also be used, efficiently and accurately, to identify and quantify glucose released by starch hydrolysis in fruit preparations, even in the presence of fruit pieces, pigments, high concentrations of sucrose and other kinds of polysaccharides (Chatel et al., 1996).

*To whom correspondence should be addressed 
In addition, G6PD can be employed for glucose determination in several beverages and in amended soil (Frey et al., 1999; Mori et al., 1999). This enzyme can also detect low levels of streptavidin and biotin by bioluminescent assays in DNA hybridization reactions, without enzymatic activity loss (Balaguer et al., 1989; Terouanne et al., 1989). As a biosensor the enzyme G6PD can rapidly monitor the concentration of glucose 6-phosphate (G6P) in blood or human tissue at lower costs, and consuming less time than the traditional methods like chromatography or spectroscopy. This monitoring is important because it can directly reflect the relative activity of G6PD in the metabolic pathways, and has been utilized to provide insight into the regulation of G6PD in human erythrocytes and rat liver cells (Bassi et al., 1999).

S. cerevisiae has been widely used for expression of various genes for protein production. As an eukaryotic organism, this yeast is a suitable host for high level production of both secreted and soluble cytosolic proteins. The $S$. cerevisiae PGK1 (phosphoglycerate kinase 1) gene encodes one of the most abundant mRNA and protein species in the cell, accounting for between $1 \%$ and $5 \%$ of the total cellular mRNA and protein. Therefore, the PGK1 promoter is an attractive option to obtain high levels of protein expression (Lojudice et al., 2001).

The goal of this work was to improve the Glucose-6-phosphate dehydrogenase production by Saccharomyces cerevisiae W303-181 (genetically modified S. cerevisiae), which carries a plasmid containing the G6PD coding sequence under the control of the PGK1 promoter. Because G6PD is a constitutive enzyme, its production from a microorganism is linked to the amount of biomass obtained from a cultivation process. However, attaining a high amount of cell mass depends on the variables evaluated, such as: $\mathrm{pH}$ value, inoculum concentration and initial glucose concentration. The common approach of studying one variable at a time, while keeping the others constant within a set of selected values, has the drawbacks of requiring a large number of experiments and missing the interactions among the variables. An alternative, as employed in this work, is the use of statistical experimental designs, which require fewer experiments (Box et al., 1978). This methodology allows the verification of the effects of the variables individually, and their interactions on the enzyme production (Hasmann et al., 2003). A statistical model correlating the variables allowed the optimization of the cultivation process, with particular attention to the enzyme productivity.
Although G6PD could be attained from several microbial species, in Brazil, the use of $S$. cerevisiae as a source of this enzyme and other products (Godfrey and West, 1996) is practical owing to the large experience in handling this strain in industrial plants. In addition, coupling the yeast processing with ethanol production probably should have a positive effect on distillery profits.

\section{MATERIALS AND METHODS}

\section{Chemicals}

Yeast Nitrogen Base (YNB), aminoacids, nicotinamide adenine dinucleotide phosphate (NADP), phenylmethylsulfonyl fluoride (PMSF), $\beta$ mercaptoethanol, glucose 6-phosphate (G6P) and glucose were purchased from Sigma Chemical Company (St. Loius, MO). GOD/POD enzymatic kit was purchased from Laborlab (Brazil). All the other chemicals were of analytical grade.

\section{Microorganism and Inoculum Preparation}

Saccharomyces cerevisiae W303-181 genetically modified was employed in all experiments; genetic techniques were described in details by Lojudice et al. (2001). The stock culture was maintained at $4^{\circ} \mathrm{C}$ on agar slants containing: yeast nitrogen base (YNB) $7.4 \mathrm{~g} / \mathrm{L}$, glucose $20 \mathrm{~g} / \mathrm{L}$, adenine $20 \mu \mathrm{g} / \mathrm{mL}$, Ltryptophan $20 \mu \mathrm{g} / \mathrm{mL}$, uracil $20 \mu \mathrm{g} / \mathrm{mL}$, L-Histidine $20 \mu \mathrm{g} / \mathrm{mL}$. A loopful of the stock culture was transferred to a $250 \mathrm{~mL}$ Erlenmeyer flask containing $50 \mathrm{~mL}$ of medium previously prepared with the same composition of stock culture and sterilized. For inoculum preparation, the cultures were incubated on a rotary shaker (NBS Gyratory Shaker, New Brunswick Scientific Company, New Brunswick) at $150 \mathrm{rpm}, 30^{\circ} \mathrm{C}$ for $24 \mathrm{~h}$. Following, the cells were separated by centrifugation $\left(8720 \mathrm{~g} ; 4^{\circ} \mathrm{C}\right.$ for $30 \mathrm{~min}$ ), and rinsed with distilled water.

\section{Growth Conditions}

The inoculum was transferred to a $250 \mathrm{~mL}$ Erlenmeyer flask containing $50 \mathrm{~mL}$ of medium under the conditions $(\mathrm{pH}$ value, inoculum concentration and initial glucose concentration) indicated by the statistical experimental design, shown in Table 1. The flask was left under agitation of $150 \mathrm{rpm}$ at $30^{\circ} \mathrm{C}$, untill the total exhaustion of the carbon source. The medium composition was similar to that 
used in the inoculum preparation (yeast nitrogen base $7.4 \mathrm{~g} / \mathrm{L}$, adenine $20 \mu \mathrm{g} / \mathrm{mL}$, L- tryptophan $20 \mu \mathrm{g} / \mathrm{mL}$, uracil $20 \mu \mathrm{g} / \mathrm{mL}$, L-Histidine $20 \mu \mathrm{g} / \mathrm{mL}$ ) always maintaining constant the ratio $\mathrm{C} / \mathrm{N}$ with the alteration of the variable initial glucose concentration, and the $\mathrm{pH}$ value adjusted with buffer solutions (buffered medium with $0.1 \mathrm{M}$ acetate solution).

\section{Experimental Design and Statistical Analysis}

To verify the influence of $\mathrm{pH}$ value, inoculum concentration and initial glucose concentration on the enzyme productivity $\left(y_{\mathrm{PrG} 6 \mathrm{PD}}\right)$, a $2^{3}$ factorial design augmented with orthogonal design was employed. For each of the three variables, high (coded value: +1 ), medium (coded value: 0 ) and low (coded value: -1 ) set points were selected (Table 1). Cultivations representing all the set point combinations were performed, and the assays G6PD productivity $\left(\operatorname{Pr}_{\mathrm{G} 6 \mathrm{PD}}\right)$ and cell productivity $\left(\mathrm{Pr}_{\text {cell }}\right)$ were conducted randomly. They were taken as the dependent variables or responses of the design experiments. The "Statgraphics" (version 6.0) software was used for regression and graphical analysis of the data obtained, following traditional methodology for statistical analysis.

\section{Measurement of Cell and Glucose Concentrations}

One milliliter of fermenting medium was centrifuged (8720 g; $10 \mathrm{~min}$ - Jouan centrifuge, Saint Herblain/France), and the supernatant was used to measure glucose concentration via the GOD/POD enzymatic kit (Laborlab, kit number 02200). The cell cake was used to measure the cell concentration values of the cultures. This was obtained by using a calibration curve correlating optical density, measured through a spectrophotometer at $600 \mathrm{~nm}$ (Beckman DU 640) with dry weight (g/L).

Table 1: Experimental design and results of the $2^{3}$ full factorial orthogonal composite design.

\begin{tabular}{|c|c|c|c|c|c|c|c|}
\hline \multirow{2}{*}{ Run } & \multicolumn{3}{|c|}{$\begin{array}{c}\text { Variables }^{\mathrm{a}} \\
\text { coded value (actual value) }\end{array}$} & \multicolumn{4}{|c|}{ Responses $^{b}$} \\
\hline & $x_{1}$ & $\mathbf{x}_{2}$ & $\mathbf{x}_{3}$ & $\begin{array}{l}P_{\mathbf{P r}_{\text {G6PD }}} \\
\text { (U/L.h) }\end{array}$ & $\begin{array}{c}P_{\text {cell }} \\
\text { (g/L.h) }\end{array}$ & $\mathrm{U} / \mathrm{L}$ & $\mathbf{U} / \mathbf{g}_{\text {cell }}$ \\
\hline 1 & $-1(4.8)$ & $-1(0.1)$ & $-1(20.0)$ & 45.6 & 0.035 & 1594.2 & 1189.7 \\
\hline 2 & $+1(6.6)$ & $-1(0.1)$ & $-1(20.0)$ & 29.0 & 0.022 & 1393.2 & 297.7 \\
\hline 3 & $-1(4.8)$ & $+1(1.1)$ & $-1(20.0)$ & 20.3 & 0.037 & 735.3 & 404.0 \\
\hline 4 & $+1(6.6)$ & $+1(1.1)$ & $-1(20.0)$ & 18.4 & 0.029 & 904.1 & 428.5 \\
\hline 5 & $-1(4.8)$ & $-1(0.1)$ & $+1(40.0)$ & 0.3 & 0.009 & 28.0 & 27.4 \\
\hline 6 & $+1(6.6)$ & $-1(0.1)$ & $+1(40.0)$ & 2.3 & 0.014 & 177.4 & 151.6 \\
\hline 7 & $-1(4.8)$ & $+1(1.1)$ & $+1(40.0)$ & 11.4 & 0.027 & 776.2 & 356.0 \\
\hline 8 & $+1(6.6)$ & $+1(1.1)$ & $+1(40.0)$ & 4.9 & 0.013 & 590.2 & 322.5 \\
\hline 9 & $0(5.7)$ & $0(0.6)$ & $0(30.0)$ & 14.2 & 0.018 & 810.6 & 547.7 \\
\hline 10 & $0(5.7)$ & $0(0.6)$ & $0(30.0)$ & 11.8 & 0.016 & 669.7 & 488.9 \\
\hline 11 & $0(5.7)$ & $0(0.6)$ & $0(30.0)$ & 13.4 & 0.018 & 762.2 & 529.3 \\
\hline 12 & $0(5.7)$ & $0(0.6)$ & $0(30.0)$ & 12.9 & 0.018 & 756.8 & 518.4 \\
\hline 13 & $-1(4.8)$ & $0(0.6)$ & $0(30.0)$ & 17.0 & 0.022 & 1068.5 & 722.0 \\
\hline 14 & $+1(6.6)$ & $0(0.6)$ & $0(30.0)$ & 18.6 & 0.022 & 1205.2 & 767.3 \\
\hline 15 & $0(5.7)$ & $-1(0.1)$ & $0(30.0)$ & 19.6 & 0.027 & 881.5 & 663.8 \\
\hline 16 & $0(5.7)$ & $+1(1.1)$ & $0(30.0)$ & 13.3 & 0.040 & 1277.1 & 544.8 \\
\hline 17 & $0(5.7)$ & $0(0.6)$ & $-1(20.0)$ & 35.6 & 0.047 & 1373.8 & 743.8 \\
\hline 18 & $0(5.7)$ & $0(0.6)$ & $+1(40.0)$ & 6.2 & 0.019 & 681.6 & 449.6 \\
\hline 19 & $0(5.7)$ & $0(0.6)$ & $0(30.0)$ & 12.8 & 0.028 & 974.0 & 527.3 \\
\hline 20 & $0(5.7)$ & $0(0.6)$ & $0(30.0)$ & 11.0 & 0.027 & 943.9 & 527.3 \\
\hline
\end{tabular}

${ }^{a} \mathrm{x}_{1}=\mathrm{pH}$ value; $\mathrm{x}_{2}=$ inoculum concentration $\left(\mathrm{X}_{0}, \mathrm{~g} / \mathrm{L}\right)$; and $\mathrm{x}_{3}=$ initial glucose concentration $\left(\mathrm{S}_{0}, \mathrm{~g} / \mathrm{L}\right) ;{ }^{\mathrm{b}} \operatorname{Pr}_{\mathrm{G} 6 \mathrm{PD}}=$ enzyme productivity (U/L.h); $\mathrm{Pr}_{\text {cell }}=$ cell productivity (g/L.h); U/L or U/g cell = enzyme production (by medium volume or cell concentration) 


\section{G6PD Activity Assays}

The cells were resuspended in $50 \mathrm{mM}$ Tris- $\mathrm{HCl}$ buffer ( $\mathrm{pH} 7.5$ ) containing $5 \mathrm{mM} \mathrm{MgCl}_{2}, 0.2 \mathrm{mM}$ EDTA, $\quad 10 \mathrm{mM} \quad \beta$-mercaptoethanol, $\quad 2 \mathrm{mM}$ aminocaproic acid and $1 \mathrm{mM}$ PMSF (phenyl methyl sulfonyl fluoride). The cell suspension was disrupted by submitting to a vortex (PHOENIX AP56, Araraquara, Brazil) in the presence of glass beads (diameter $=0.5 \mathrm{~mm})$ at low temperature $\left(<10^{\circ} \mathrm{C}\right)$. The wet cell cake, Tris-HCl buffer and glass beads were mixed in a volumetric proportion of about 1:8:1. Cell debris and glass beads were removed by centrifugation $\left(8720 \mathrm{~g} ; 10 \mathrm{~min} ; 4^{\circ} \mathrm{C}\right)$ and the G6PD activity of the supernatant was measured by spectrophotometric quantitation of reduced $\mathrm{NADP}^{+}$ at $30^{\circ} \mathrm{C}$, as described by Bergmeyer (1984). One G6PD unit (U) was defined as the amount of enzyme catalyzing the reduction of $1 \mu \mathrm{mol}$ of $\mathrm{NADP} / \mathrm{min}$ under the assay conditions.

\section{Calculation of Cultivation Parameters}

The substrate-to-cell conversion factor was calculated as $\mathrm{Y}_{\mathrm{X} / \mathrm{S}}=\Delta \mathrm{X} / \Delta \mathrm{S}$; the enzyme productivity as $\operatorname{Pr}_{\mathrm{G} 6 \mathrm{PD}}=\Delta \mathrm{P} / \Delta \mathrm{t}$; and the cell productivity as $\operatorname{Pr}_{\text {cell }}=$ $\Delta \mathrm{X} / \Delta \mathrm{t}$, in which $\Delta \mathrm{X}=\mathrm{X}_{\mathrm{f}}-\mathrm{X}_{\mathrm{o}}\left(\mathrm{X}_{\mathrm{f}}=\right.$ final cell concentration and $X_{o}=$ initial cell concentration), $\Delta S$ $=\mathrm{S}_{\mathrm{o}}-\mathrm{S}_{\mathrm{f}}\left(\mathrm{S}_{\mathrm{o}}=\right.$ initial glucose concentration and $\mathrm{S}_{\mathrm{f}}=$ final glucose concentration $), \Delta \mathrm{P}=\mathrm{P}_{\mathrm{f}}-\mathrm{P}_{\mathrm{o}}\left(\mathrm{P}_{\mathrm{f}}=\right.$ final enzymatic activity and $\mathrm{P}_{\mathrm{o}}=$ initial enzymatic activity), and $\Delta t=t_{f}-t_{o}\left(t_{f}=\right.$ final cultivation time and $t_{o}=$ initial cultivation time). The specific cell growth rate $\left(\mu_{\mathrm{X}}\right)$, specific substrate consumption rate $\left(\mu_{\mathrm{S}}\right)$ and specific G6PD production rate $\left(\mu_{\mathrm{P}}\right)$ were defined in Equations 1, 2 and 3:

$$
\begin{aligned}
& \mu_{x}=\frac{1}{X} \frac{d X}{d t} \\
& \mu_{S}=\frac{1}{X} \frac{d S}{d t} \\
& \mu_{p}=\frac{1}{X} \frac{d P}{d t}
\end{aligned}
$$

The derivatives $\mathrm{dX} / \mathrm{dt}, \mathrm{dS} / \mathrm{dt}$, and $\mathrm{dP} / \mathrm{dt}$ were calculated according to the method proposed by Le Duy and Zajic (1973). The coefficient of cell maintenance $\left(\mathrm{m}_{\mathrm{s}}\right)$ is represented by the linear coefficient of the equation obtained of the plot between $\mu_{\mathrm{s}}$ as a function of $\mu_{\mathrm{x}}$ (Pirt, 1965) (Equation 4). The parameter substrate-to-cell true conversion factor, $Y_{G}$, is calculated, from Equation 4 , as the inverse of the angular coefficient $(1 / \mathrm{a})$.

$\mu_{\mathrm{s}}=\mathrm{a} \cdot \mu_{\mathrm{x}}+\mathrm{m}_{\mathrm{s}}$

\section{RESULTS AND DISCUSSION}

The yeast used in this work was recently developed by genetic modification (Lojudice et al., 2001), and the effects of different experimental conditions on cell and G6PD productivities during aerobic cultivations, at $30^{\circ} \mathrm{C}$, were simultaneously investigated by employing a full factorial experimental design. The three evaluated variables were: $\mathrm{pH}$ value, inoculum concentration and initial glucose concentration. The $\mathrm{pH}$ values were chosen based on previous results reported by Abrahão-Neto et al. (1997), while the inoculum concentration (initial yeast concentration) and initial glucose concentration were chosen based on previous results referred by Silva et al. (2002). To maintain constant the $\mathrm{C} / \mathrm{N}$ ratio $(\mathrm{C} / \mathrm{N}=7)$, the nitrogen concentration (from YNB and aminoacids) in the cultivation medium was changed as a function of carbon source concentration (initial glucose concentration). The design of this experiment, given in Table 1, was planned to obtain a quadratic model consisting of $2^{3}$ trials plus an orthogonal configuration, with replicates at the center point and with the experimental productivity results.

According to Table 1, the highest cell and G6PD productivity values were reached when the genetically modified $S$. cerevisiae was cultivated at the lowest level of substrate concentration $(20.0 \mathrm{~g} / \mathrm{L})$, and a probable repression of the enzyme synthesis at high glucose concentrations was observed. Anyway, the experimental data were statistically evaluated to verify the effect of the variables on the desired responses (enzyme and cell productivity) (Tables 2 and 3). Regression analysis was performed to fit the response functions, G6PD productivity $\left(\operatorname{Pr}_{\mathrm{G} 6 \mathrm{PD}}\right)$ and cell productivity $\left(\mathrm{Pr}_{\text {cell }}\right)$ as a function of the experimental data. The negative effects, shown in Tables 2 and 3, mean that the increase of the variable values causes productivity decreases. 
Effect of Cultivation Conditions on Glucose-6-Phosphate Dehydrogenase Production

Table 2: Estimated effects, standard errors and Student's $t$-test for G6PD productivity $\left(\operatorname{Pr}_{\mathrm{G} 6 \mathrm{PD}}\right)$ using the $2^{3}$-full factorial orthogonal composite design.

\begin{tabular}{|l|c|c|c|c|}
\hline Variables & Estimated Effects & Standard errors & $\boldsymbol{t}$-values & $\boldsymbol{P}^{\mathbf{a}}$ \\
\hline mean & 14.15 & 0.90 & 15.71 & 0.000 \\
$\mathrm{x}_{1}$ & -2.13 & 0.88 & -2.40 & 0.035 \\
$\mathrm{x}_{2}$ & -2.84 & 0.88 & -3.19 & 0.009 \\
$\mathrm{x}_{3}{ }^{2}$ & -12.37 & 0.88 & -13.90 & 0.000 \\
$\mathrm{x}_{3}$ & 4.19 & 1.37 & 3.04 & 0.011 \\
$\mathrm{x}_{2} \cdot \mathrm{x}_{3}$ & 6.21 & 0.99 & 6.24 & 0.000 \\
$\mathrm{x}_{1} \cdot \mathrm{x}_{2} \cdot \mathrm{x}_{3}$ & -2.89 & 0.99 & -2.91 & 0.014 \\
\hline
\end{tabular}

a significant level of the variables, and their interactions

Table 3: Estimated effects, standard errors and Student's $t$-test for cell productivity ( $\left.\operatorname{Pr}_{\text {cell }}\right)$ using the $2^{3}$-full factorial orthogonal composite design.

\begin{tabular}{|l|c|c|r|}
\hline Variables & Estimated Effects & Standard errors & t-values \\
\hline mean & 0.023 & 0.001 & 17.28 \\
$\mathrm{x}_{1}$ & -0.003 & 0.001 & -2.50 \\
$\mathrm{x}_{2}$ & 0.004 & 0.001 & 3.27 \\
$\mathrm{x}_{3}{ }^{2}$ & -0.009 & 0.001 & -7.67 \\
$\mathrm{x}_{1}{ }^{2}$ & -0.006 & 0.002 & -2.51 \\
$\mathrm{x}_{2}{ }^{2}$ & 0.006 & 0.002 & 0.037 \\
$\mathrm{x}_{3}$ & 0.005 & 0.002 & 0.000 \\
\hline
\end{tabular}

${ }^{\text {a }}$ significant level of the variables, and their interactions

As the main objective of this work was to obtain the highest productivity in enzyme $\left(\mathrm{Pr}_{\mathrm{G} 6 \mathrm{PD}}\right)$, a model expressed by Equation 5 was calculated, and shows the G6PD productivity ( $\left.y_{\mathrm{PrG} 6 \mathrm{PD}}\right)$ as a function of the following coded values: $\mathrm{pH}$ value $\left(\mathrm{x}_{1}\right)$, inoculum concentration $\left(\mathrm{x}_{2}\right)$ and initial substrate or initial glucose concentration $\left(\mathrm{x}_{3}\right)$.

$$
\begin{aligned}
& \mathrm{y}_{\operatorname{PrG} 6 \mathrm{PD}}=14.15-2.13 \mathrm{x}_{1}-2.84 \mathrm{x}_{2}-12.37 \mathrm{x}_{3}+ \\
& 4.19 \mathrm{x}_{3}{ }^{2}+6.21 \mathrm{x}_{2} \mathrm{x}_{3}-2.89 \mathrm{x}_{1} \mathrm{x}_{2} \mathrm{x}_{3}
\end{aligned}
$$

To simplify the model $y_{\mathrm{PrG} \text { (PD }}$ (Eq. 5) and draw the response surface, the variable $\mathrm{x}_{2}$ was replaced by its minimum codified value $(-1)$, condition at which the highest enzyme productivity value was obtained. Thus, a new statistical model is shown in Equation 6.

$\mathrm{y}_{\text {PrG6PD }}=17.00-2.13 \mathrm{x}_{1}-18.58 \mathrm{x}_{3}+$

$4.19 \mathrm{x}_{3}^{2}+2.89 \mathrm{x}_{1} \mathrm{x}_{3}$

Another model expressed by Equation 7 was calculated, and shows the cell productivity $\left(y_{\text {cell }}\right)$ as a function of the $\mathrm{pH}$ value $\left(\mathrm{x}_{1}\right)$, inoculum concentration $\left(\mathrm{x}_{2}\right)$ and substrate (glucose) concentration $\left(\mathrm{x}_{3}\right)$, coded values.

$$
\begin{aligned}
& \mathrm{y}_{\text {cell }}=0.023-0.003 \mathrm{x}_{1}+0.004 \mathrm{x}_{2}-0.009 \mathrm{x}_{3}- \\
& 0.006 \mathrm{x}_{1}^{2}+0.006 \mathrm{x}_{2}^{2}+0.005 \mathrm{x}_{3}^{2}
\end{aligned}
$$

To simplify the cell productivity model (Eq. 7) and draw the response surface, the variable $\mathrm{x}_{2}$ was again replaced by its minimum codified value (-1), condition at which the highest enzyme productivity value was obtained, and a new statistical model is shown in Equation 8.

$$
\begin{aligned}
& \mathrm{y}_{\text {cell }}=0.025-0.003 \mathrm{x}_{1}-0.009 \mathrm{x}_{3}- \\
& 0.006 \mathrm{x}_{1}^{2}+0.005 \mathrm{x}_{3}^{2}
\end{aligned}
$$

The statistical significance of the second-order model for $\operatorname{Pr}_{\mathrm{G} 6 \mathrm{PD}}$ was evaluated by the analysis of variance (ANOVA), which revealed that the regression obtained for this model is statistically significant ( $99 \%$ of confidence level). The response surface described by the model G6PD productivity $\left(y_{\mathrm{PrG} F \mathrm{PD}}\right)$ is represented in Figure 1. For the response cell productivity $\left(\mathrm{Pr}_{\text {cell }}\right)$, the statistical significance of the model revealed that the regression obtained is also statistically significant. The response surface described by the cell productivity model $\left(y_{\text {cell }}\right)$ is represented in Figure 2. 
According to the response surfaces, which represent G6PD and cell productivities (Figures 1 and 2), and comparing to the codified values (Table 1$)$, the highest enzyme productivity $\left(\operatorname{Pr}_{\mathrm{G} 6 \mathrm{PD}}=\right.$ 45.6 U/L.h) was obtained when the variables were $\mathrm{pH}=4.8, \mathrm{X}_{0}=0.1 \mathrm{~g} / \mathrm{L}$ and $\mathrm{S}_{0}=20 \mathrm{~g} / \mathrm{L}$. On the other hand, the highest cell productivity $\left(\mathrm{Pr}_{\text {cell }}=\right.$ $0.047 \mathrm{~g} / \mathrm{L} . \mathrm{h})$ was obtained under $\mathrm{pH}=5.7, \mathrm{X}_{0}=$ $0.6 \mathrm{~g} / \mathrm{L}$ and $\mathrm{S}_{0}=20 \mathrm{~g} / \mathrm{L}$.

Saccharomyces cerevisiae cultivations are mainly performed in the $\mathrm{pH}$ range from 4.0 to 5.0, since bacterial contamination is highly unfavorable (Lima et al., 2001). Furthermore, Lima et al. (2001) emphasize that $\mathrm{pH}$ can be diminished down to 2.0 without damaging cell profile. However, the authors affirm that cultivations carried out at about $\mathrm{pH} 5.8$ also provide excellent results. Concerning glucose effects, in general glucose represses enzyme synthesis (Entian et al., 1985). This fact could be observed in our experiments, since the cultivations conducted at the highest initial glucose concentrations $(40 \mathrm{~g} / \mathrm{L})$ provided the lowest enzyme productivities.

To confirm the predicted response $\left(y_{\mathrm{PrG} 6 \mathrm{PD}}\right)$ by the simplified model, as well as to do a kinetic study, a new cultivation was carried out by employing the optimal conditions $\left(\mathrm{pH}=4.8, \mathrm{X}_{0}=0.1 \mathrm{~g} / \mathrm{L}\right.$, and $\mathrm{S}_{0}=$ $20 \mathrm{~g} / \mathrm{L}$, under $150 \mathrm{rpm} / 30^{\circ} \mathrm{C}$ ). The results, shown in Figure 3, indicate that glucose consumption, and enzyme production and cell production are coupled

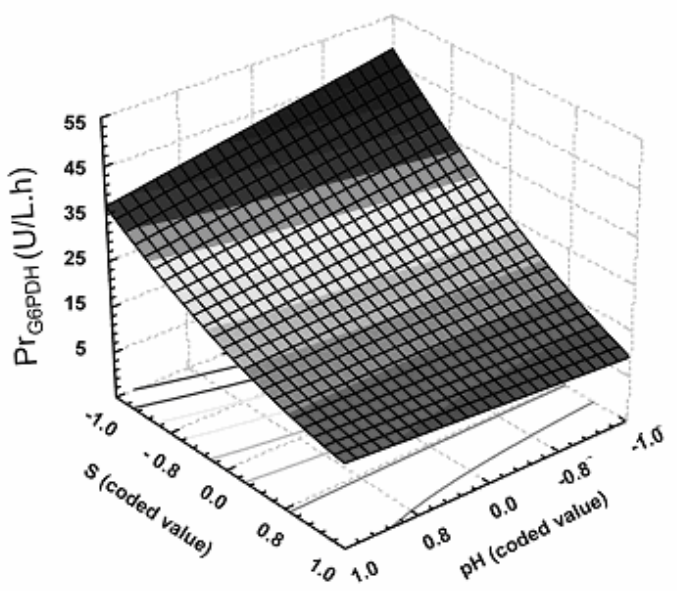

Figure 1: Response surface described by the model which represents G6PD productivity by S. cerevisiae W303-181 as a function of initial glucose concentration ( $\mathrm{S}$, coded values) and $\mathrm{pH}$ (coded values), $\mathrm{X}_{\mathrm{o}}=0.1 \mathrm{~g} / \mathrm{L}$. events. The obtained enzyme productivity was similar to that predicted by the model and consequently by the response surface. This figure also shows that after about 30 hours of cultivation, the substrate was totally consumed, the cell growth was at the stationary phase and the enzyme activity was at the highest level. The maximal specific cell growth rate $\left(\mu_{\mathrm{X}, \max }\right)$ value of $0.15 \mathrm{~h}^{-1}$ was similar $\left(0.16 \mathrm{~h}^{-1}\right)$ to that obtained by Silva et al. (2002) and by Miguel et al. (2003). Considering that, for recombinant systems with a high copy number of plasmid per cell, the host growth rate decreases because of the presence and expression of the plasmids, the maximal specific cell growth rate obtained here is quite good. In the present case, we can assume that the cultivation conditions guaranteed an adequate amount of nutrient in the medium to fine-tune the metabolic pathways related to growth, production and substrate consumption, with $0.059 \mathrm{~g} / \mathrm{g}$ for the $\mathrm{Y}_{\mathrm{X} / \mathrm{S}}$ value.

The results presented in Figure 3 were used to calculate the kinetic parameters of the process. Figure 4 presents the linear correlation, expressed by Equation 9, between specific substrate consumption rate $\left(\mu_{\mathrm{S}}\right)$ and specific cell growth rate $\left(\mu_{\mathrm{X}}\right)$ (Moser, 1985). During cell growth and enzyme production, part of the substrate was consumed for maintenance of the cell metabolism $\left(\mathrm{m}_{\mathrm{S}}=0.053 \mathrm{~h}^{-1}\right)$, and for byproduct production (for instance, ethanol). Thus, the substrateto-cell true conversion factor $\left(\mathrm{Y}_{\mathrm{G}}\right)$ was $0.089 \mathrm{~g} / \mathrm{g}$.

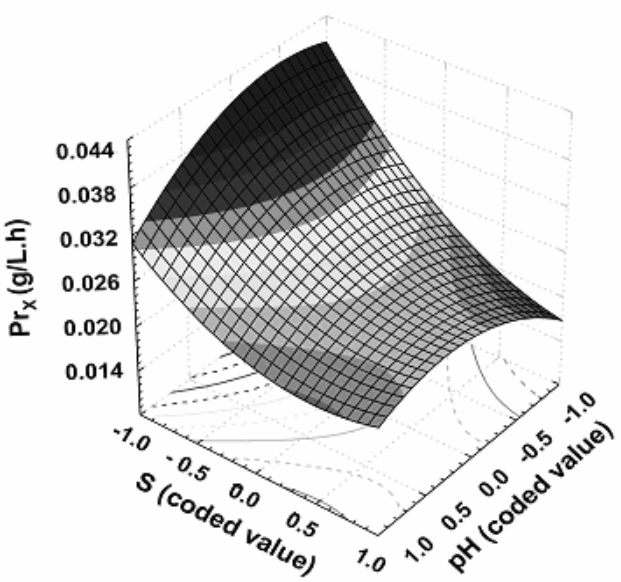

Figure 2: Response surface described by the model which represents cell productivity by S. cerevisiae W303-181 as a function of initial glucose concentration ( $\mathrm{S}$, coded values) and $\mathrm{pH}$ (coded values), $\mathrm{X}_{\mathrm{o}}=0.1 \mathrm{~g} / \mathrm{L}$. 


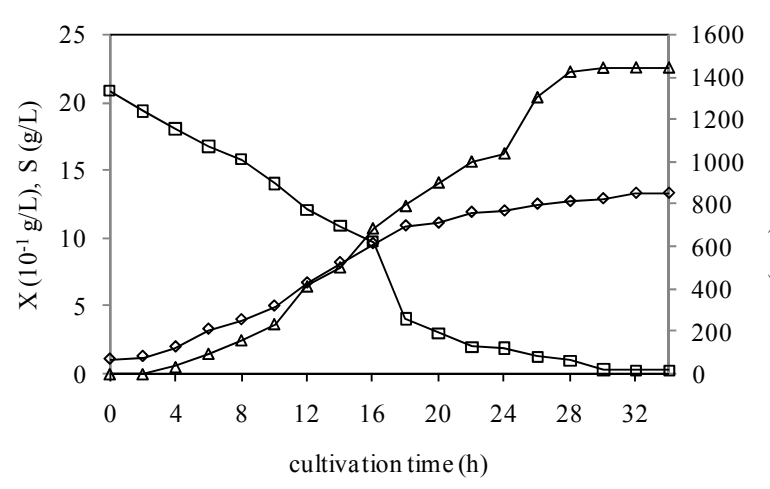

Figure 3: Cell concentration (X, $\diamond)$, glucose concentration $(S, \square)$ and enzymatic activity (G6PD, $\Delta)$ as a function of cultivation time (h) of Saccharomyces cerevisiae W303-181, performed under the following conditions: $\mathrm{pH}=4.8, \mathrm{X}_{\mathrm{o}}=$ $0.1 \mathrm{~g} / \mathrm{L}$, and $\mathrm{S}_{0}=20.0 \mathrm{~g} / \mathrm{L}$ (under agitation of $150 \mathrm{rpm}$ at $30^{\circ} \mathrm{C}$ ).

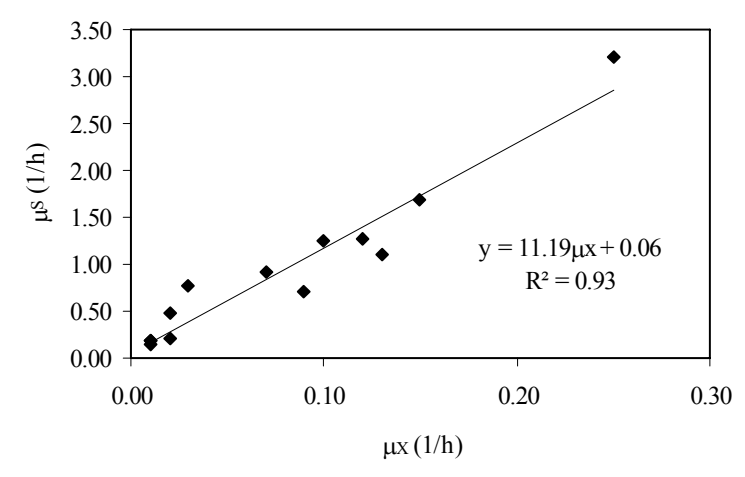

Figure 4: Specific substrate consumption rate $\left(\mu_{\mathrm{S}}\right)$ as a function of specific G6PD production rate $\left(\mu_{\mathrm{P}}\right)$ determined after cultivation of Saccharomyces cerevisiae W303-181 performed under the following conditions: $\mathrm{pH}=4.8, \mathrm{X}_{\mathrm{o}}=$ $0.1 \mathrm{~g} / \mathrm{L}$, and $\mathrm{S}_{\mathrm{o}}=20.0 \mathrm{~g} / \mathrm{L}$ (under agitation of $150 \mathrm{rpm}$ at $30^{\circ} \mathrm{C}$ ).

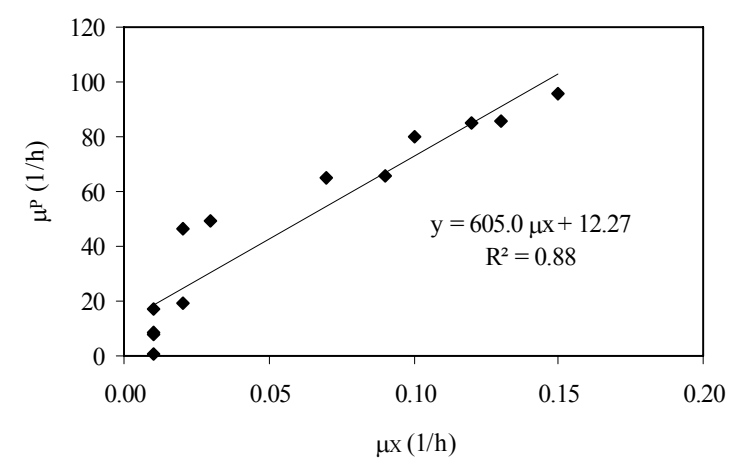

Figure 5: Variation in G6PD specific production rate $\left(\mu_{\mathrm{P}}\right)$ as a function of growth rate $\left(\mu_{\mathrm{X}}\right)$ calculated after cultivation of Saccharomyces cerevisiae W303-181 performed under the following conditions: $\mathrm{pH}=$ $4.8, \mathrm{X}_{\mathrm{o}}=0.1 \mathrm{~g} / \mathrm{L}$, and $\mathrm{S}_{\mathrm{o}}=20.0 \mathrm{~g} / \mathrm{L}$ (under agitation of $150 \mathrm{rpm}$ at $30^{\circ} \mathrm{C}$ ).

The specific G6PD production rate $\left(\mu_{\mathrm{P}}\right)$ and specific cell growth rate $\left(\mu_{\mathrm{X}}\right)$ can be reasonably correlated by the approach proposed by Luedeking and Piret (2004), shown in Figure 5, expressed by Equation 10. Assuming that the linear coefficient is negligible, G6PD formation and growth rate are associated events. As this enzyme is constitutive and growth-related, a viable process for its production would be in a steady-state continuous culture (Vitolo et al., 1985).

$$
\begin{array}{ll}
\mu_{\mathrm{s}}=11.19 \mu_{\mathrm{X}}+0.06 & \left(\mathrm{R}^{2}=0.93\right) \\
\mu_{\mathrm{P}}=605 \mu_{\mathrm{X}}+12.3 & \left(\mathrm{R}^{2}=0.88\right)
\end{array}
$$

The enzyme produced by the genetically modified S. cerevisiae cultivated in the experimental optimal conditions $\left(\mathrm{pH}=4.8, \mathrm{X}_{0}=0.1 \mathrm{~g} / \mathrm{L}\right.$, and $\mathrm{S}_{0}=$ $20 \mathrm{~g} / \mathrm{L}$, under $150 \mathrm{rpm} / 30^{\circ} \mathrm{C}$ ) was compared to the wild $S$. cerevisiae employing a suspension in the same concentration obtained in the optimal condition of cultivation with the modified yeast. The enzymatic activity (G6PD production) of the genetically modified strain (1594 U/L) was up to 21 times higher than the enzyme activity from the wild type $(75.9 \mathrm{U} / \mathrm{L})$.

\section{CONCLUSIONS}

It can be concluded that the high level of G6PD formation and productivity $\left(y_{\mathrm{PrG} 6 \mathrm{PD}}\right)$ by $S$. cerevisiae W303-181 is associated with cell growth. This paper also showed that, under the optimized culture conditions $(\mathrm{pH}$ maintained at 4.8 , inoculum 
concentration of $0.1 \mathrm{~g} / \mathrm{L}$ and initial glucose concentration of $20 \mathrm{~g} / \mathrm{L}$, under $150 \mathrm{rpm} /$ temperature of $30^{\circ} \mathrm{C}$ ), G6PD activity obtained for a modified $S$. cerevisiae was about 21 times higher than of a wild strain. Undoubtedly, this modified strain is an important potential source of G6PD. The proposed modified Saccharomyces cerevisiae, containing promoters that are up regulated, has been demonstrated to be an interesting potential source of G6PD.

\section{NOMENCLATURE}

$\begin{array}{ll}\mathrm{G} 6 \mathrm{PD} & \begin{array}{l}\text { enzyme glucose-6- } \\ \text { phosphate dehydrogenase } \\ \text { coefficient of cell } \\ \text { maintenance } \\ \mathrm{m}_{\mathrm{S}}\end{array} \\ \mathrm{Pr}_{\text {cell }} & \begin{array}{l}\text { cell productivity } \\ \mathrm{Pr}_{\mathrm{G} 6 \mathrm{PD}}\end{array} \\ \mathrm{U} / \mathrm{L} & \begin{array}{l}\text { G6P productivity } \\ \text { enzyme production by } \\ \text { medium volume }\end{array} \\ \mathrm{U} / \mathrm{g}_{\text {cell }} & \begin{array}{l}\text { enzyme production by cell } \\ \text { concentration } \\ \text { determination coefficient }\end{array} \\ \mathrm{R}^{2} & \begin{array}{l}\text { initial glucose concentration } \\ \text { pH coded value (model) }\end{array} \\ \mathrm{S}_{0} & \begin{array}{l}\text { inoculum concentration } \\ \mathrm{x}_{1}\end{array} \\ \mathrm{x}_{2} & \begin{array}{l}\text { coded value (model) } \\ \text { initial glucose concentration }\end{array} \\ \mathrm{x}_{3} & \begin{array}{l}\text { coded value (model) } \\ \text { initial cell concentration (or }\end{array} \\ \mathrm{X}_{0} & \begin{array}{l}\text { inoculum concentration) } \\ \text { G6PD productivity (model) }\end{array} \\ y_{\mathrm{PrG} 6 \mathrm{PD}} & \begin{array}{l}\text { cell productivity (model) } \\ \text { substrate-to-cell true }\end{array} \\ y_{\text {cell }} & \begin{array}{l}\text { conversion factor } \\ \mathrm{Y}_{\mathrm{G}}\end{array} \\ \mathrm{Y}_{\mathrm{X} / \mathrm{S}} & \begin{array}{l}\text { substrate-to-cell conversion } \\ \text { factor }\end{array} \\ & \end{array}$

\section{Greek Letters}

$\begin{array}{llc}\mu_{\mathrm{X}} & \text { specific cell growth rate } & 1 / \mathrm{h} \\ \mu_{\mathrm{S}} & \text { specific substrate } & 1 / \mathrm{h} \\ & \text { consumption rate } & \\ \mu_{\mathrm{P}} & \text { specific G6PD production rate } & 1 / \mathrm{h} \\ \mu_{\mathrm{X}, \max } & \text { maximal specific cell } & 1 / \mathrm{h} \\ & \text { growth rate } & \end{array}$

\section{ACKNOWLEDGEMENTS}

Fernanda Guerreiro Rossi acknowledges receipt of fellowship from FAPESP (Fundação de Amparo à
Pesquisa do Estado de São Paulo / Brazil). The authors also acknowledge the financial support from CNPq (Conselho Nacional de Desenvolvimento Científico e Tecnológico/Brasil), CAPES (Coordenadoria de Aperfeiçoamento de Pessoal de Ensino Superior / Brazil); and Prof. Carla Columbano Oliveira for supplying the genetically modified yeast.

\section{REFERENCES}

Abrahão-Neto, J., Infanti, P. and Vitolo, M., Influence of $\mathrm{pH}$ temperature and dissolved oxygen concentration on the production of glucose-6-phosphate dehydrogenase and invertase by Saccharomyces cerevisiae, Braz. J. Chem. Eng. 14, 89-94 (1997).

Balaguer, P., Térouanne, B., Eliaou, J. F., Humbert, M., Boussioux, A. M. and Nicolas, J. C., Use of glucose-6-phosphate dehydrogenase as a new label for nucleic acid hybridization reactions, Anal. Biochem. 180, 50-54 (1989).

Bassi, A. S., Tang, D. Q. and Bergougnou, M. A., Mediated amperometric biosensor for glucose-6phosphate monitoring based on entrapped glucose-6-phosphate dehydrogenase, $\mathrm{Mg}+2$ ions, tetracyanoquinodimethane, and nicotinamide adenine dinucleotide phosphate in carbon paste, Anal. Biochem. 268, 223-228 (1999).

Bergmeyer, H. U., Methods of Enzymatic Analysis, In: Bergmeyer, H. U., Bergmeyer, J. and Grasl, M. (eds) Methods of Enzymatic Analysis vol.2, 3rd, Verlag Chemie, Weinheim (1984).

Box, G. E. P., Hunter, W. G. and Hunter, J. S., Statistics for Experimenters: an Introduction to Design, Data Analysis and Model Building, John Wiley \& Sons, New York (1978).

Chatel, S., Voirin, A., Luciani, A. and Artaud, J., Starch identification and determination in sweetened fruit preparations, J. Agric. Food. Chem..44, 502-506 (1996).

Entian, K. D., Hilberg, F., Opitz, H. and Mecke, D., Cloning of hexokinase structural genes from Saccharomyces cerevisiae mutants with regulatory mutations responsible for glucose repression, Mol. Cell. Biol. 5, 3035-3040 (1985).

Frey, S. D., Elliott, E. T. and Paustian, K., Application of the hexokinase-glucose-6phosphate dehydrogenase enzymatic assay for measurement of glucose in amended soil, Soil Biol. Biochem. 31, 933-935 (1999).

Godfrey, T. and West, S., Industrial Enzymology, 2nd, MacMillan, London (1996). 
Hasmann, F. A., Cortez, D. V., Pessoa-Jr, A. and Roberto, I. C., Optimization of $\beta$-xylosidase recovery by reversed micelles using response surface methodology, Electron. J. Biotechn. 6, 20-27 (2003).

Ivison, F. M., Kane, J. W., Pearson, J. E., Kenny, J. and Vadgama, P., Development of a redox mediated amperometric detection system for immunoassay: Application to urinary amphetamine screening, Electroanal. 12, 778-785 (2000).

Le Duy, A. and Zajic, J. E., A geometrical approach for differentiation of an experimental function at a point applied to growth and product formation, Biotechnol. Bioeng. 15, 805-810 (1973).

Lima, U. A., Aquarone, E. A., Borzani, W. and Schmidell, W., Biotecnologia Industrial: Processos Fermentativos e Enzimáticos, v.3, Edgard Blücher Ltda, São Paulo (2001).

Lojudice, F. H., Silva, D. P., Zanchin, N. I. T., Oliveira, C. C. and Pessoa-Jr, A., Overexpression of glucose-6-phosphate dehydrogenase (G6PD) in genetically modified Saccharomyces cerevisiae. Appl. Biochem. Biotechnol. 91-93, 161-169 (2001).

Luedeking, R. and Piret, E. L., A kinetic study of the lactic acid fermentation - Batch process at controlled pH, J. Biochem. Microbiol. Tech. Eng. 1, 393-412 (2004).

Miguel, A. S. M., Neves, L. C. M., Vitolo, M. and Pessoa-Jr, A., Effect of flow rate pattern on glucose-6-phosphate dehydrogenase synthesis in fed-batch culture of recombinant Saccharomyces cerevisiae, Biotechnol. Prog. 19, 320-324 (2003).

Mori, H., Ishida, M. and Okamoto, S., Glucose determination using a flow system with enzyme reactor and application to analysis of glucose content in beverages, J. Health Sci. 45, 126-129 (1999).

Moser, A., Kinetics of Batch Fermentations In: Rehm, H. J. and Reed, G. (eds) Biotechnology: Fundamentals of Biochemical Engineering v.2, VCH Publishers, Weinheim (1985).

Pirt, S.J., The maintenance energy of bacteria in growing cultures, Proc. R. Soc. Lond. B. Biol. Sci. 163, 224-231 (1965).

Silva, D. P., Pessoa-Jr, A., Roberto, I.C. and Vitolo, M., Effect of $\mathrm{K}_{\mathrm{L}} \mathrm{a}$ on the production of glucose-6phosphate dehydrogenase from Saccharomyces cerevisiae grown by fermentation process, Appl. Biochem. Biotechnol. 98-100, 205-213 (2002).

Terouanne, B., Bencheick, M., Balaguer, P., Boussioux, A. M. and Nicolas, I.C., Bioluminescent assays using glucose-6-phosphate dehydrogenase - Application to biotin and streptavidin detection, Anal. Biochem. 180, 43-49 (1989).

Vitolo, M., Vairo, M. L. R. and Borzani, W., Invertase activity of intact-cells of Saccharomyces cerevisiae growing on sugar-cane molasses: steady-state continuous culture tests, Biotechnol. Bioeng. 27, 1229-1235 (1985). 